\title{
超音波によるプラスチックの結晶化度の測定
}

\author{
西脇信彦*・崔 愛玲*・今野政昭*・堀 三計*
}

\section{A New Ultrasonic Method of Measuring the Crystallinity of Molded Thermoplastics}

\author{
Nobuhiko NishiwakI*, Ailing CuI*, \\ Masaaki KonNo*, Sankei HorI*
}

\begin{abstract}
Presently, injection moldings of thermoplastics are widely used in many industries. When a crystalline or semi-crystalline thermoplastic is used, the crystallinity of the molded part can be directly related to its quality, that is, shrinkage, mechanical strength and so on. Many methods for measuring of the crystallinity have thus been proposed, although it is not very easy to measure the crystallinity.

In this paper, a new method of measuring the crystallinity of a molded part was developed. The crystallinity can be obtained in a nondestructive way by measuring the longitudinal sound velocity traveling through it because the sound velocity which is mainly related to the Young's modulus is different between amorphous and crystalline states. The measurement on a molded plate of high density polyethylene was carried out.
\end{abstract}

Key words : Injection molding/Crystallinity/High density polyethylene/Sound velocity/ Young's modulus

\section{1. 緒言}

プラスチックの射出成形加工は，金型内へ溶融した 樹脂を充填し，急冷させて成形する方法である．結晶 性樹脂の場合は冷却速度により結晶化度すなわち収縮 量が異なる、そのため, 成形品にそりやねじれが生じ る.な拉, 結晶化度は上述の収縮量のほかに機械的強

* 東京農工大学 工学部 機珹システム工学科 小金并市中町 2-24-16 (

Department of Mechanical Systems Engineering, College of Engineering, Tokyo University of Agriculture and Technology

2-24-16 Naka-cho, Koganei, Tokyo 184, Japan 1993. 8. 7 受理
度やYoung 率と密接な関係がある1)。さらに CAE に よる熱解析で必要となる熱伝導率や比熱等とも関係し てくるため, 非常に重要な值である.

結晶化度の測定方法 ${ }^{2), 3}$ ) としては, 密度, DSC (示 差走查熱量計 $\left.)^{4}\right), X$ 線回析, 赤外線吸収等が用いられ る.特に前二者がよく用いられるが，これらの方法を 用いて結晶化度分布を求めるには個々に成形品を小片 に切り出す必要がある. これに対して, 後二者の方法 は一般に薄片の測定に適して拈り, 成形品を薄く切り 出すことにより厚さ方向の分布を求めることができる が，簡単に測定することが難しい、したがって，簡単 にかつ任意の点の局所的結晶化度分布を測定する良い 方法が無いのが現状である. 
そこで本研究では，超音波を用いることにより成形 品の任意の位置での結晶化度を簡単に測定する方法を 新たに開発した。具体的には樹脂中の音速と結晶化度 の関係から，成形品中の音速分布を測定することによ り結晶化度分布を求める方法である.

\section{2. 測 定 原 理}

結晶性樹脂を成形した場合, 一般的に完全な結晶状 態とはならず，アモルファス状態を含んだ不完全な結 晶状態となる，そこで，樹脂の結晶化度 $X_{c}$ 、は，(1) 式に示すようにアモルファス状態と完全結晶状態の割 合で定義され，密度 $\rho$ または比容積 $V$ の值を測定す ることにより求められる. 本研究では成形品の密度を エチルアルコールと蒸溜水の混合液による浮沈法で測 定し, その密度の值を(1)式へ代入して結晶化度を求 めた. な护，(1)式の添字の $a$ と $c$ はアモルファス 状態と完全結晶状態に和ける值である。

$$
X_{c}=\frac{\rho_{c}}{\rho} \cdot \frac{\rho-\rho_{a}}{\rho_{c}-\rho_{a}}=\frac{V_{a}-V}{V_{a}-V_{c}}
$$

いっぽら, 固体中の縱波音速 $U(\mathrm{~m} / \mathrm{s})$ および横波 音速 $U_{t}(\mathrm{~m} / \mathrm{s})$ は, その Young 率を $E\left(\mathrm{~Pa}=\mathrm{N} / \mathrm{m}^{2}\right)$, 密度を $\rho\left(\mathrm{N} \cdot \mathrm{s}^{2} / \mathrm{m}^{4}\left(=\mathrm{kg} / \mathrm{m}^{3}\right)\right)$, Poisson 比をレとす ると，それぞれ次式のようになる。

$$
\begin{aligned}
U & =\sqrt{\frac{E(1-\nu)}{\rho(1+\nu)(1-2 \nu)}} \\
U_{t} & =\sqrt{\frac{E}{2 \rho(1-\nu)}}
\end{aligned}
$$

なお，両式から Poisson 比を消去すると, Young 率 と音速の関係は次式のようになる。

$$
E=\frac{\rho U_{t}^{2}\left(4 U_{t}^{2}-3 U^{2}\right)}{U_{t}^{2}-U^{2}}
$$

また，Poisson 比レと音速の関係は次式のようにな る.

$$
\nu=\frac{U^{2}-2 U_{t}^{2}}{2 U^{2}-2 U_{t}^{2}}
$$

\section{3. 測 定 方 法}

上記のように成形品中の縱波音速のほかに横波音速 を測定すると Young 率や Poisson 比の值をで求ま るので, 両音速の測定を行った. 使用した縦波用超音 波送受信子は振動子直径が $3.18 \mathrm{~mm}$, 周波数 $20 \mathrm{MHz}$ (PANAMETRICS 社製 M 208) で横波用超音波送受 信子は振動子直径 $6.35 \mathrm{~mm}$, 周波数 $5 \mathrm{MHz}$ (PANAMETRICS 社製 V 156) である.な扮，成形品の局所 的な縦波音速分布の測定を行う場合には, 超音波送受 信子の先端に音響レンズを取り付けて測定を行った。 その場合, 超音波を直径約 $0.2 \mathrm{~mm}$ をで絞って測定を

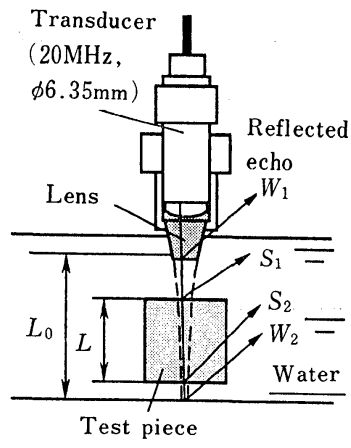

Reflected echo on CRT

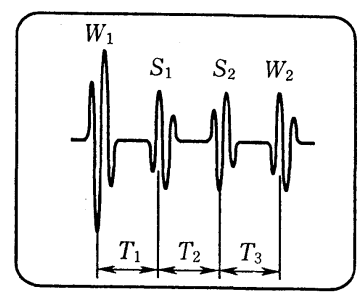

Fig. 1 Measurement of sound velocity by using ultrasonic technique

行った.

縱波音速の測定方法は, Fig. 1 に示すような容器の 中へ音速が既知である水を満たし，その中へ成形品を 入れてパルス反射法 ${ }^{5}$ とより測定を行った。測定の初 めに，超音波送受信子々容器底面までの距離 $L_{0}$ をあ らかじめ測定した. 具体的には, 超音波が容器の底面 で反射し超音波送受信子まで戻って来る時間間隔 $T_{0}$ を測定し, 水中の音速 $U_{w}$ の值を用いて, 超音波送 受信子から容器の底面までの距離 $L_{0}\left(T_{0} \cdot U_{w} / 2\right)$ を 測定した.

次に, 超音波送受信子と容器底面の間へ成形品を挿 入すると，同図に示すような反射波形が得られる.す なわち音響レンズ面と水の境界面から反射してくる反 射波 $W_{1}$, 成形品の両表面と水の境界面から反射して くる反射波 $S_{1}, S_{2}$, 扩よび容器の底面から反射してく る反射波 $W_{2}$ が観察される．そこでそれぞれの反射波 形間の時間間隔を $T_{1}, T_{2}, T_{3}$ とすると, 音響的に観 察した成形品の厚さ $L$ およびその音速 $U_{p}$ は, 次式 のようになる。

$$
\begin{aligned}
& L=L_{0}-\frac{U_{w}\left(T_{1}+T_{3}\right)}{2} \\
& U_{p}=\frac{2 L}{T_{2}}
\end{aligned}
$$

横波の音速測定の場合は, 横波超音波送受信子を直 接成形品の表面に押し当て，パルス反射法 ${ }^{5}$ により測 定した。な和，使用した樹脂は高密度ポリエチレン (HDPE) である. 
Table 1 Molding condition

\begin{tabular}{l|c}
\hline Nozzle Temperature $\left({ }^{\circ} \mathrm{C}\right)$ & 220 \\
Injection pressure $(\mathrm{MPa})$ & $36.5 \sim 72.9$ \\
Injection speed $(\mathrm{mm} / \mathrm{s})$ & 30.5 \\
Holding pressure $(\mathrm{MPa})$ & 36.5 \\
Mold temperature $\left({ }^{\circ} \mathrm{C}\right)$ & $20 \sim 80$ \\
Clamping force $(\mathrm{kN})$ & 882 \\
\hline
\end{tabular}

\section{4 , 結果と考察}

\section{1 音速と結晶化度の関係}

本研究では, 実際に Table 1 に示すよらな種々の条 件で成形された，厚さ $3 \mathrm{~mm}$ の $\mathrm{HDPE}\left(\rho_{a}=860 \mathrm{~kg} /\right.$ $\left.\mathrm{m}^{3}, \rho_{c}=1000 \mathrm{~kg} / \mathrm{m}^{3}\right)$ の成形品から一辺約 $3 \mathrm{~mm}$ の四 角の試験片を切り出し, その結晶化度を浮沈法で測定 すると同時に，その厚さ方向の縦波音速および横波音 速を，すなわち配向方向と垂直な方向の音速を測定し た. 結晶化度と縦波音速の関係を Fig. 2 飞. 結晶化 度と横波音速の関係を Fig. 3 にそれぞれ示す。これ らの図に沶いて，音速と結晶化度の関係が多少ばらつ いているのは，配向ひずみやその他の要因によるもの と考学られるが，近似的には緹波音速または横波音速

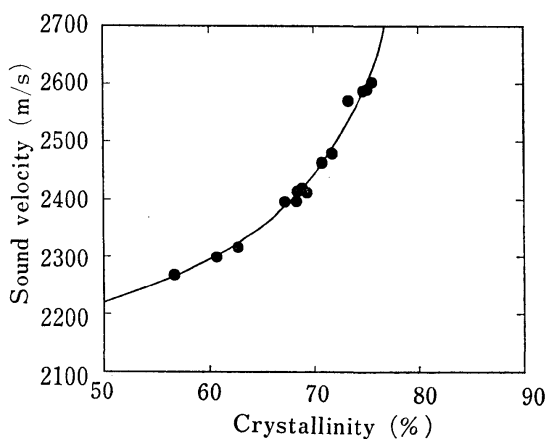

Fig. 2 Relationship between crystallinity and longitudinal sound velocity (HDPE)

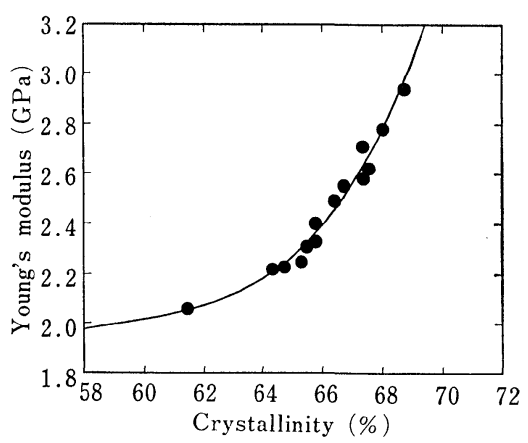

Fig. 4 Relationship between Young's modulus and crystallinity (HDPE)
を測定することにより，成形品の結晶化度が求められ ることがわかる．な拉，横波音速の場合には，同一の 試験片でも樹脂の流動方向に沿って横波音速を測定す る場合と流動方向と直角方向に測定する場合では横波 音速が異なり，後者の方がわずかに横波音速が低くな る結果が得られた。

いっぽう，(1)式より結晶化度は密度のみの関数で あり, 密度が増加すると結晶化度が単調增加する。こ こで. Young 率や Poisson 比が結晶化度により变化 しないと仮定して，(2)式または（3)式より音速と密 度の関係について考える.（1)式より結晶化度が増加 すると密度が増加して，(2)，（3 式より音速は減少 することになり，Fig. 2，Fig. 3 と異なる結果とな る.

そこで（4)式（5)式を用いて Young 率 $E$ と Poisson 比עの值を算出した。ただし，綎波音速が樹 脂の流動方向と直角方向の值であるので横波音速の值 としては同じく流動方向 と直角方向で測定した横波 音速の值を用いて計算した。 その結果，結晶化度と Young 率の関係を Fig. 4 飞, 結晶化度と Poisson 比を Fig. 5 に示す.これらの図より，結晶化度によ り Poisson 比はほとんど変化しないが，Young 率は

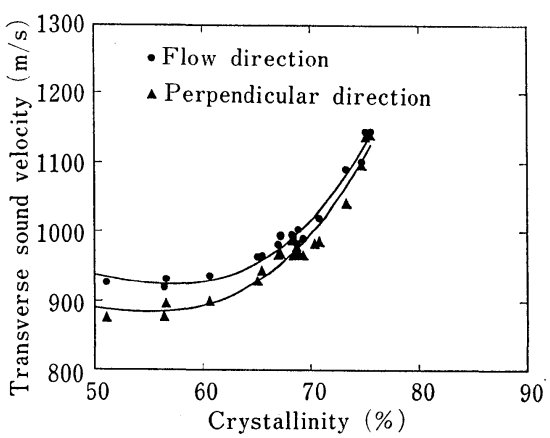

Fig 3 Relationship between crystallinity and transverse sound velocity (HDPE)

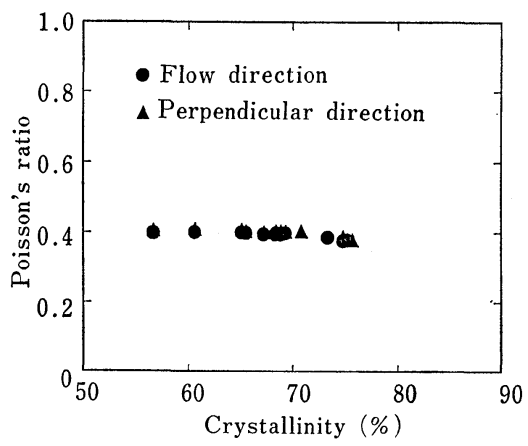

Fig. 5 Relationship between crystallinity and Poisson's ratio (HDPE) 


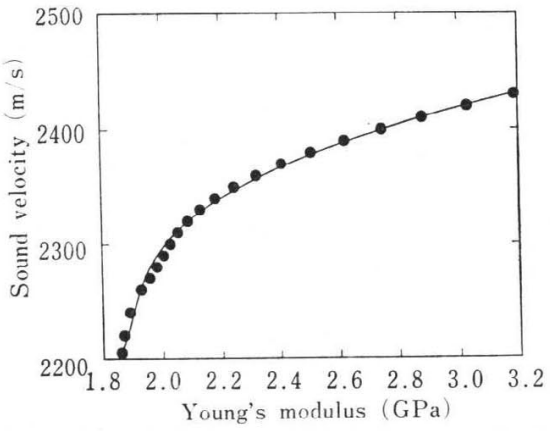

Fig. 6 Relationship between Young's modulus and longitudinal sound velocity (HDPE)

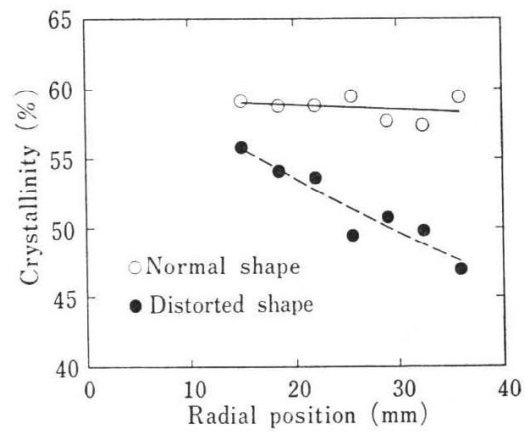

Fig. 8 Crystallinity distributions along radial direction

大きく変化することが明らかとなった．したがって， 結晶化度の增加に伴い音速が増加する原因は, 密度の 増加により音速を小さくさせる効果よりる, Young 率による音速を大きくする効果の方が大きいためと考 えられる.すなわち, 結晶化度が增大すると密度も増 加するが，それ以上に Young 率が大きく増大し，そ の結果, 音速が增大すると考えられる.

そこで Young 率と音速の関係を求めると Fig. 6 に示すようになり, 音速を測定すると結晶化度だけで なく Young 率の挙動も間接的に測定できることが明 らかとなった。

\section{2 成形品物性}

実際に，厚さ $1 \mathrm{~mm}$ で直径 $80 \mathrm{~mm}$ の円盤を金型温 度や射出条件を種々変化させて成形した結果, 正常な 形状の成形品と㸚じれた形状の成形品が成形された。 その代表的な成形品を Fig.7 (a) に示す. また，そ の変形挙動を測定した結果を Fig. 7 (b) に示す. こ の 2 つの円艋の半径方向の縱波音速分布を測定し,

Fig. 2 の実駼結果を用いて音速を結晶化度へ換算する と Fig. 8 に示すようになり, 正常な形状の場合は半 径方向に対してほぼ一定の綐波音速になるのに対し，

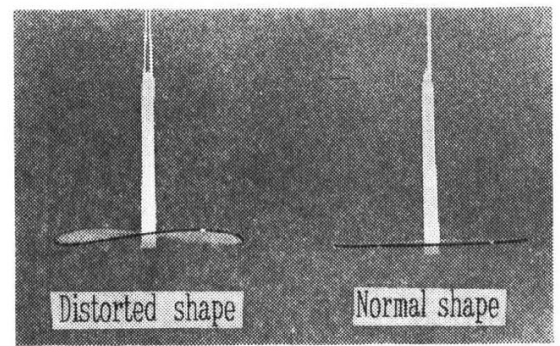

Fig. 7 (a) Part Shape

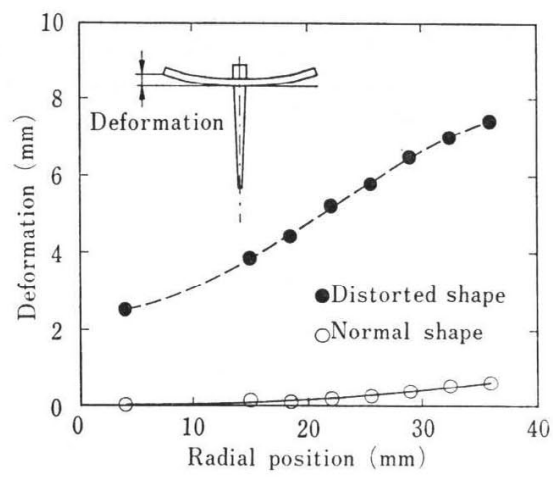

Fig 7 (b) Deformation of circular disk along radial direction

ねじれた形状の場合は半径の增加と共に縦波音速が低 下する挙動を示す. このことは Fig. 2 の結果より. 正常な形状の場合はほぼ一様な結晶化度となり, ほぽ 一様な収縮状態となっているのに対し，ねじれた形状 の場合は中心付近では結晶化度が高いため収縮量が大 きく, 半径が大きくなるに従って結晶化度が低くな り, 収縮量が小さくなるため, ねじれた形状になった と思われる.

次に, 厚さ $3 \mathrm{~mm}$, 長さ $150 \mathrm{~mm}$, 幅 $40 \mathrm{~mm}$ の形状 に成形されたものの中央部分上り一辺 $3 \mathrm{~mm}$ の立方体 形状に切り出した試料について，その厚さ方向の縱波 音速分布を焦点形超音波送受信子 (測定径約 $0.2 \mathrm{~mm}$ ) を用いて測定した結果と，Fig. 2 の実験結果を用いて 音速を結晶化度へ換算した結果を Fig. 9 に示す. 同 図(a) は樹脂の流動方向と平行な面で厚さ方向に測定 した結果であり, 同図(b) は樹脂の流動方向と垂直な 面で厚さ方向に測定した結果である.な报，参考のた めに金型表面と接している面上で樹脂の流動方向と平 行な方向および直角な方向に測定した結果を同図(c) に示す. また, Fig. 2 の音速は樹脂の流動方向之直角 な方向へ超音波を伝播させたときの音速であるので， Fig. 9(b) の結晶化度は同図(a) の結晶化度を転記し てある。 


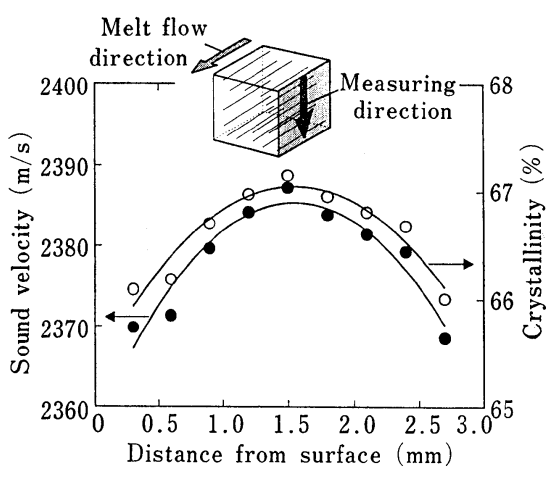

Fig. 9(a) Longitudinal Sound velocity and crystallinity distributions in the parallel direction to melt flow

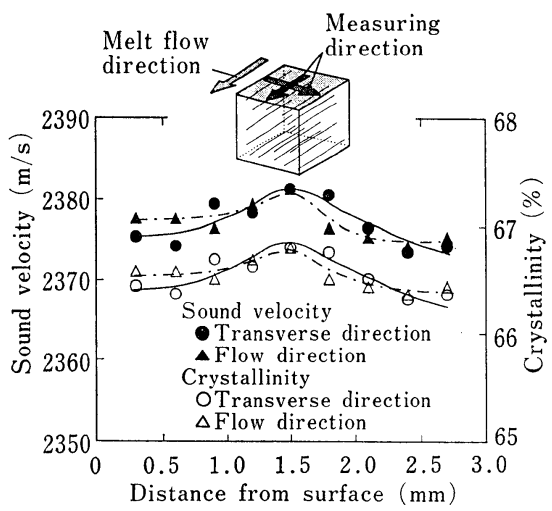

Fig. 9(c) Longitudinal sound velocity and crystallinity distributions on molded surface

Fig. 9 (a) に示されるように, 成形品中の縱波音速 は厚さ方向に均一でなく，金型と接する表面近傍の音 速が遅く，逆に厚さの中央付近で音速が速くなってい る.これは金型内で樹脂が固化するとき，金型と接す る付近の樹脂は急冷され，金型キャビティ中央付近で は冷却速度が遅くなるため, 結晶化度が中央付近で高 くなり，金型と接する付近で低くなるためと考觉られ る.な扐，Fig. 9 (c) 飞示すように，成形品の表面か ら測定した值と Fig. 9 (a)の平均値とはほぼ一致して いる. いっぽう, Fig.9（b) に示すように，樹脂の流 動方向之平行方向の音速分布はそれと直角方向の分布 と注涪同じ挙動を示すが，流動方向の音速の值の方が 高くなっている.

以上のように，焦点形の縱波超音波送受信子を用い れば，成形品中の縱波音速分布を詳細調べることが でき, 結晶化度の局所的な測定ができることが明らか となった。

なお，以上の全ての測定は $20^{\circ} \mathrm{C} \pm 0.1^{\circ} \mathrm{C}$ の温度環

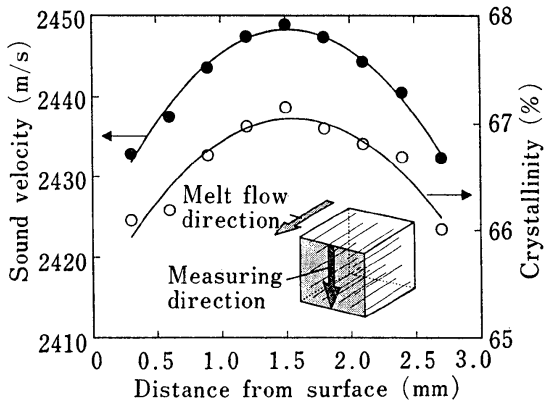

Fig. 9 (b) Longitudinal sound velocity distribution in the perpendicular direction to melt flow

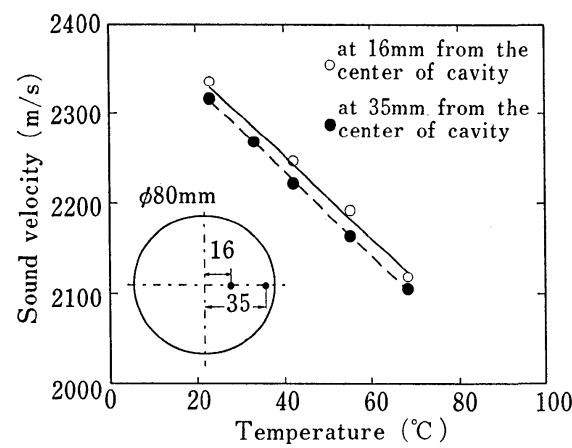

Fig. 10 Relationship between longitudinal sound velocity of molded disk and temperature

境下で測定を行ったが，成形品の温度により音速が变 化すると考兄られるので，ほぼ正常な形状に成形され た直径 $80 \mathrm{~mm}$ の円艋の半径 $16 \mathrm{~mm}$ の位置と半径 $35 \mathrm{~mm}$ の位置における縱波音速と温度の関係を調べた。その 結果 Fig. 10 亿示すように温度变化に伴ってほ泳直線 的に音速が低下することが明らかとなった。すなわ ち，温度が $20^{\circ} \mathrm{C}$ 上昇すると音速が約 $10 \%$ 低下すると 考兄ると，音速による比較測定を行う場合には測定時 の温度差が $0.2^{\circ} \mathrm{C}$ 以下であることが必要であることが 明らかとなった。

\section{5. 結 言}

成形された高密度ポリエチンン樹脂中の音速と結晶 化度怙よび Young 率などの関係を調べた結果，以下 のようなことが明らかとなった。

(1) 成形された樹脂中の縱波音速和よび横波音速は 結晶化度抒よび Young 率の值により変化するの で，それらの関係をあらかじめ求めて打けば，音 速を測定することにより間接的に結晶化度和よび Young 率の值を求めることができる. 
（2) 樹脂中の縦波および横波音速は，樹脂の流動方 方向に沿って測定した場合の方が流動方向之直角 向で測定した場合より速くなる.

（3）焦点形超音波送受信子を用いることにより，局 所的な縱波音速分布を測定することができ，結晶 化度の局所的な分布が間接的に測定できる．ただ し，縱波音速は温度により変化するので，同じ温 度状態で音速を比較する必要がある.
参考 文 献

1) de Candia, F. et al.: Polym. Eng. Sci. 28 (15) 974 (1988)

2）藤山光美，脇野哲夫：成形加工，1 (4) 388(1990)

3) Krevelen, D. W. van and Hoftyzer, P. J.: Properties of Polymers, 423 (1980) Elsevier Science Publishing, Amsterdam.

4) Ludwig, H.-J.: et al.: Polym. Eng. Sci. 28 (3) 143 (1988)

5）日本学術振興会製鋼第19委員会編：超音波探傷法, (1974)

文献抄録

\section{Polymer}

\section{-Vol.34, No. 15}

Dosiére, M.: Orientation of the Lamellar Crystals in Polyamide 12 (p. 3160)

「ポリアミド 12 に拉けるラメラ結晶の配向」

Moitzi, J. and Skalicky, P.: Shear-induced Crystallization of Isotactic Polypropylene Melts :

Isothermal WAXS Experiments with Synchrotron Radiation (p. 3168)

「アイソタクチックポリプロピレン融体のせん断誘起結晶化: シンクロトロンを放射を用いた等温 WAXS 実験」

Bos, H. L. and Donald, A. M.: The Deformation Behaviour of Thin Films of Poly (sryreneacrylonitrile)/Poly (styrene-maleic anhydride) brends (p. 3191)

「ポリ（スチレンーアクリロニトリル）共重合体/ポリ（スチレン一無水マレイン酸）共重合体ブレンド物 フィルムの変形挙動」

Eashoo, M., Shen, D., Wu, Z., Lee, C. J., Harris, F. W. and Cheng, S. Z. D.: High-performance Aromatic Polyimide Fibers: 2. Thermal Mechanical and Dynamic Properties (p. 3209)

「高性能芳香族ポリイミド䋐維 : 2. 機械的, 動力学的特性」

Lucas, J. C., Borrajo, J. and Williams, R. J. J.: Cure of Unsaturated Polyester Resins : 1. Heat of Copolymerization and Glass Transition Temperature (p.3216)

「不飽和ポリエステル樹脂の硬化：1. 共重合熱量和よびガラス転移点」

Ho, R. M., Su, A.C., Wu, C.H. and Chen, S. I.: Functionalization of Polypropylene via Melt Mixing (p. 3264)

「溶融混合によるポリプロピレンの機能化」

- Vol. 34, No. 16

Silverstein, M.S. and Breuer, O.: Wettability and Flotation of Etched Ultra High Molecular Weight Polyethylene Fibres (p.3421)

「ェッチング処理された超高分子量ポリエチレンのぬれ性と浮水性」

Koh, S.-W., Kim, J.-K. and Mai, Y.-W.: Fracture Toughness and Failure Mechanisms in

Silica-filled Epoxy Resin Composites : Effects of Temperature and Loading Rate (p. 3446)

「シリカ充填エポキシ樹脂の破壊じん性と破壊メカニズム : 充填量と温度の関係」

Green, D. I., Davies, G. R. and Ward,I. M.: Orientational Changes Induced by Axial Stress

in a Highly Aligned Liquid Crystalline Copolyester (p. 3526)

「高度に配向した液晶コポリエステルの軸方向応力により誘起された配向変化」 